\title{
A RESIDENTIAL AREA CITIZENS' ATTITUDE TOWARDS ENVIRONMENT OF LIVING IN THE DOMESTIC AND EUROPEAN CONTEXT
}

\author{
M. Prášilová, P. Varvažovská
}

Received: June 29, 2012

\begin{abstract}
PRÁŠILOVÁ, M., VARVAŽOVSKÁ, P.: A residential area citizens' attitude towards environment of living in the domestic and European context. Acta univ. agric. et silvic. Mendel. Brun., 2012, LX, No. 7, pp. 225-232

The paper is offering an assessment of the citizens' attitude towards the environment of living, it is examining peoples' considerate behaviour within the environment and whether people are willing to do something in favour of the environment, and how far they are interested in the information as concerns the environment. A detailed analysis is looking into the opinion as concerns activities of some of the institutions in connection with environment problems, ecological responsibility of the population, of the organisations and the State. The research is covering topical social and economic problems perception by the public, too, both in domestic and international milieu. The paper analyzes results of the questionnaire survey done on a random sample of people in the Karlovarský Region residential area in 2012. Data obtained have been assessed statistically using qualitative analysis methods. Included in the questionnaire have been questions concerning the citizens' opinion about European integration and about globalisation in the sense of environment. The survey conclusions demonstrate current citizens' attitude towards levels and importance of the environment in everyday life.
\end{abstract}

environment, public opinion, ecological responsibility, environmental perception, State institutions, citizen, questionnaire survey, statistical analysis

Environment is a complex system of natural, artificial and social components of material nature inclusive of permanent interaction of these. The impact of human society upon their environment is many-sided. People have violated, damaged and influenced their environment from time immemorial. A big shock upon the environment in recent epoch was caused by the industrial revolution beginning. Twentieth century was environment-devastating on the one side, however, on the other side it laid foundations for environment-protective activities within human society. Protection of the environment becomes a more and more complicated and dynamically developing system of human activities from both global and national (local) viewpoint. Nowadays it is an obvious duty of every developed country to protect all particular components of the environment, to eliminate negative impacts of sectors of the economy upon the environment, to set up the system of environmental policy instruments, to study influence of environment upon human health and the ecosystems and to materialize the particular measures as concerns the environment in international context. The relationship between society and environment and the importance of environment for development and quality of human life becomes a priority within the objectives of European Union policies. However, improvement of environment quality for the benefit of man must not become an obstacle in permanently sustainable development of all the components of the environment. The social environment protection strategy has to be a long-term, conceptual and systematic action involving an active participation of the society and every citizen. However, the two of these disagree often in their attitudes. 


\section{MATERIAL AND METHODS}

The aim of the paper is an assessment of the citizens' attitudes towards the environment, through finding out how considerately people themselves behave in their environment and whether they are willing to do something for the environment and how much they are interested in the information as concerns the environment.

The paper analyzes results of a questionnaire survey on a random sample of respondents living permanently in Karlovarský Region. The survey was aimed at finding out attitudes of the public towards some of the aspects of environment in the region affected by specific political and economic measures. Questions were aimed at the assessment of satisfaction of the adult region inhabitants with the basic components of environment and with their practical experience. The survey also touched knowledge of national and European environment policies in the population and it considered people's active participation in the formation and protection of a healthy environment. The survey conclusions assess population's attitude towards the level and importance of environment in everyday life and citizens' views on the environmental perception by the society.

Based on theoretical opening ideas an aim was established to the satisfaction of which a field survey was carried out and analyzed subsequently using the appropriate statistical methods.

\section{Analysis of the qualitative phenomena (attributes) relationships}

A relationship between the qualitative statistical data may be called an association or the contingency. Association refers to a relationship between alternative statistical variables assuming two only values (varieties). Contingency analyzes a relationship between qualitative attributes of which at least one is of a multiple (non-alternative) nature. When relationships between the qualitative statistical attributes are being examined, data available usually come from sampling. It is good to find out then, whether they are related and whether generalization of the results obtained from the sample upon the original population is possible. Such questions can be answered using testing procedures where statistical significance of the relationship between two qualitative attributes under study is verified. In the present solution $\chi^{2}$ test has been used. The test is based on null hypothesis assuming independence of the two attributes. The test criterion is defined in general by:

$\chi^{2}=\sum_{i=1}^{k} \sum_{j=1}^{m} \frac{\left(n_{i j}-o_{i j}\right)^{2}}{o_{i j}}$,

or, $\chi^{2}=\sum_{i=1}^{k} \sum_{j=1}^{m} \frac{n \times\left(n_{i j}\right)^{2}}{n_{i \bullet} \times n_{\bullet j}}-n$,

where,

n........... size of the sample,

$\mathrm{n}_{\mathrm{ij}}$.......... observed frequency,

$\mathrm{O}_{\mathrm{ij}} \ldots . . . . . . . .$. expected (theoretical) frequency,

$\mathrm{n}_{\mathrm{i},}, \mathrm{n}_{\bullet} \ldots$ marginal frequencies,

$\mathrm{i}=1,2, \ldots, \mathrm{k}$, where $\mathrm{k}$ is the number of varieties of one attribute,

$\mathrm{j}=1,2, \ldots, \mathrm{m}$, where $\mathrm{m}$ is the number of varieties of the other attribute.

Theoretical frequencies are obtained as product of the corresponding marginal frequencies over the total population size. The $\chi^{2}$ test criterion has $\chi^{2}$ distribution at $[(\mathrm{k}-1)(\mathrm{m}-1)]$ degrees of freedom. In case, $\chi^{2}$ test criterion value obtained exceeds the critical value at $\alpha$ significance level and [(k-1) $(\mathrm{m}-1)$ ] degrees of freedom, null hypothesis of independence between the two attributes can be rejected at $\alpha$ level of significance or, alternative hypothesis assuming a significant relationship (correlation) between the two attributes can be supported. Probability of the assumed correlation then is $(1-\alpha)$.

\section{Measurement of the degree of relationship between qualitative attributes}

Measurement of the degree of a statistical dependence between qualitative statistical attributes can be performed using either $\chi^{2}$ coefficients or the prediction measures. Considering nature of the survey and its organisation the analytical part of research has used measures based on the $\chi^{2}$ method. In order to measure the degree of relationship in the association table, $\mathrm{V}$ coefficient of association has been used:

$V=\sqrt{\frac{\chi^{2}}{n}}$,

where the $\chi^{2}$ coefficient is defined from (2.1) and $\mathrm{n}$ is the sample size.

The coefficient of association has identical properties as the coefficient of correlation. It assumes values within the $\langle-1 ; 1>$ limits and in case of a total dependence it is equal to \pm 1 , in case of independence it is equal to 0 .

In general contingency tables the degree of the relationship is assessed using the coefficient of mean square contingency $\mathrm{C}$ (Pearson contingency coefficient):

$C=\sqrt{\frac{\chi^{2}}{n+\chi^{2}}}$,

where the $\chi^{2}$ quantity is again defined by (2.1) and $\mathrm{n}$ is the sample size. 
The Pearson coefficient of contingency assumes zero value in case of a total independence between two qualitative statistical attributes, and it approaches the unity limit in case of a total dependence.

The degree of relationship in a contingency table has also been measured using Cramér V coefficient:

$V=\sqrt{\frac{\chi^{2}}{n(h-1)}}$,

where $h=\min (k, m)$.

\section{Theoretical opening ideas}

Citizens' participation in public life and the research of civil society in general belong to the domains that especially over the last twenty years have been enjoying high levels of interest on the part of researchers in social sciences. The interdisciplinary study of civil society has brought about notions on citizens' activities over their life in the public domain, on the non-profit sector activities, and phenomena of philanthropy or volunteering have been anchored within the society. Origins of research in this field can be found already in the Seventies of the twentieth century (Weisbrod, 1977). Since the Eighties, questions concerning civil participation became objects of research by many outstanding world Universities and research institutions in the USA and western Europe (Weisbrod, 1988). In the Czech environment interest in the civil engagement and the organized as well as non-organized civil society came up from the all-society political and economic changes started at the break of the Eighties and Nineties. Besides a number of review papers based on foreign findings, some sucessful efforts can be registered, too, trying to describe Czech civil society (Skovajsa \& Col., 2010; Mansfeldová, Kroupa, 2006; Müller, 2002) and to analyze participation of citizens in the communal and regional space (Stachová, 2008; Čmejrek \& Col., 2009). Anyway, a clear boundary between civil society and the State (in the manner of a fight for political power) or, between civil society and the market (economic exchange), does not exist, in principle (Čmejrek, Kopřiva, 2007). Civil society organisations in many cases then become bases for a later founding of political subjects. Their motivation comes up from their tendency to carry out interests not represented by the traditional political parties. This is typical especially for political life at the sub-national levels of political decision making. Level of involvement of the society in everyday life is to a measure a cultural and historical consequence. In European tradition the State has relatively extensive competences. Also the level of public wealth re-distribution is important. Re-distribution becomes a decisive attribute of public administration where the co-responsibility of civil society is a necessary legitimizing element.
Besides this, Potůček (2005) demonstrates gradual vanishing of the differences between public and private domains.

Civil society usually is considered a significant component of the modern democratic government system. A high involvement of civil society is felt especially in the domain of environment. After admission of Czech Republic to European Union the actualized State Environment Policy corresponds fully to the obligations connected with Union membership. The priority areas correspond to the Sixth Action Programme of the European Community for the Environment (Ritschelová, 2006), where, in connection with environment problems, attention is paid to efforts to increase public awareness of the environment questions. The conference "Environment for Europe" of the ministers of environment from the UN Economic Commission for Europe region, taking place in Aarhus, Denmark in June 1998 added a significant contribution to the general section of the environment law system. The generally agreed and accepted "Convention on Access to Information, Public Participation in Decision-making and Access to Justice in Environment" (The Aarhus Convention) is a break in the documents for environment and democracy. The Convention and the documents connected entered into force on 30 October 2001 (Ritschelová, 2006). The subject of the Convention goes to the heart of the relationship between people and governments. The Convention is not only an environmental agreement, it is also a Convention about government accountability, transparency and responsiveness. The Aarhus Convention grants the public rights and imposes on Parties and public authorities obligations regarding access to information and public participation and access to justice. The Aarhus Convention is also forging a new process for public participation in the negotiations and implementation of international agreements.

Soukup (2001) published the results of a comparison project for the years 1993 and 2000 in the domain of environment. The aim here was an assessment of the citizens' attitudes towards environment, a demonstration of people's perception of the particular risks and of an individual's behaviour towards environment. Compared with 1993 a decline was recorded there as concerns willingness to sacrifice a part of one's comfort to the benefit of the environment (to pay higher prices, to accept a decline in one's level of living) and also the level of perception of the environmental dangers was found reduced. An increase of activities was recorded in the area of environmental behaviour (sorting of waste, above all). No change has been recorded in the area of civil actions (petition signing, demonstrations participation).

Attention to the communal level is a position of great momentum, namely because the approach of $\mathrm{EU}$ in the area of environment protection is based to a great measure on a high quality- and developed 
process of public participation, on inter-sector co-operation and on open dialogue. The local administration bodies who are responsible to their electors for their activities and who are assessed in connection with fulfillment of the election programmes, too, are, of course, more attentive as concerns local development problems, than as it takes to the tasks defined by central aministration authorities (Gabal, 2002). It can be stated, in general, that citizens' awareness of the environment problems is affected by the activities of non-profit organisations and political parties.

\section{RESULTS}

The environment is a complex system of factors and links between these, where man plays significant active, both positive and negative roles, aimed at permanent improvement of his/her life's quality. However, this requirement often stands contrary to other elements of the system. Man, contrary to the other elements, masters technical and technological devices through which his/ her behaviour towards the environment can be influenced in time. The relationship of the today man towards the environment is based on his/her everyday experience and it is affected, too, by the social milieu where he/she is living. Czech Republic joined the European Union in 2004 and one can assume that, a CR citizen is able to perceive the environment problems in international context, too.

In 2012 an extensive survey has been carried out in the Karlovarský Region aimed at finding out and analyzing citizens' opinion on some selected aspects of the environment. Karlovarský Region was chosen as a representative of other regions since man's various activities have been in conflict with each other in this region, in the ways they can affect the environment. The region is densely forested on the one side, the agriculture here is of sub-mountain nature, the region is an area favoured by tourists and spa guests, but on the other side, the region is negatively affected by effects of coal mining in the surface mines neighbouring with the town Sokolov. The research has dealt with passive perception of the problems as well as with active citizens' participation for the benefit of the environment. The questionnaire survey was aimed at 1,500 respondents, the return rate has, anyway, only been $18.8 \%$ and some of the returns have even had to be excluded from processing due to incompleteness. Statistical processing has been carried out on the sample of 249 inhabitants over 15 years of age, from the Karlovarský Region. The average age of the respondents was 38.22 years, $53.2 \%$ were women, $66.4 \%$ of the respondents were secondary school or University graduates. Most frequently they were employees (52.8\%), 12.0\% were unemployed, 6\% respondents only were entrepreneurs. $68.8 \%$ of returns came from people living in the communities over 5,000 inhabitants. The Table I below shows the structure of respondents according to their views as concerns the environment, in general and in connection with the place of living.

Citizens show a higher rate of satisfaction with the environment at their place of living (Table I). The inhabitants of smaller communities are much more satisfied with environment quality at their place of living, while the inhabitants of large cities are less satisfied. Assessment of some of the environment components at the locality of living is demonstrated in Table II below.

As shown in Table II, people assess at worst the health aspect of the environment (noise) and, at the same time they were mostly dissatisfied with that aspect, that rises their life's comfort but causes noise, which is the road traffic density. This discord appears more and more often in the developed states. The economic face of the problem is usually stronger than the sustainable development and health. During the last five years less than $10 \%$ respondents, at an average, participated actively in

I: Satisfaction of the Karlovarsky Region citizens with their environment (in \%)

\begin{tabular}{lll}
\hline Citizens' satisfaction with environment & Yes & No \\
\hline In the Republic & 48.0 & 52.0 \\
At the place of living & 63.2 & 36.8 \\
\hline
\end{tabular}

Source: Questionnaire survey

II: Environment satisfaction structure by the Karlovarský Region inhabitants at the place of living (in \%)

\begin{tabular}{lll}
\hline \multicolumn{1}{c}{ Environment aspect } & Yes & No \\
\hline Nature cleanness & 56.4 & 43.6 \\
Free nature accessibility & 84.4 & 15.6 \\
Atmosphere cleanness & 57.6 & 42.4 \\
Surface waters cleanness & 56.4 & 43.6 \\
Drinking water quality & 72.4 & 27.6 \\
Noise level & 40.0 & 60.0 \\
Road traffic density & 41.6 & 58.4 \\
\hline
\end{tabular}

Source: Questionnaire survey 
activities beneficiary for the environment quality. The participation covered petitions, financial support, demonstrations or interventions into decision making by the State administration bodies at the place of living. Anyway, during the last five years a quarter of the number of respondents offered and rendered their help at the greenery renewal or landscape conservation, at least once. The worst attitude towards environment is felt on the part of firms (73.2\%), insufficiency of recourse is condemned (70.8\%), and people assume that, the environment is affected at worst by road traffic (66.8\%) and construction (60.8\%). A relatively high percentage of respondents (more than $80 \%$ ) do not appreciate environment protection activities by the top level Government authorities, or they are not at all in the position to assess these. On the contrary, more than half of the number of respondents positively valuate activities of the ecologic organisations and they appreciate the beneficial attitude towards environment protection on the part of municipal authorities. Most of the respondents feel a lack of information on environment (66.8\%) in spite of their being interested in these (63.6\%). The differences in the region inhabitants' responses concerning sufficient or insufficient information seem connected with the education level and level of living. High school graduates and especially the University graduates declare sufficient information more often. Also the inhabitants at a good level of living express more satisfaction with the information, while those at a worse level are not so satisfied.

The respondents' households usually sort their dangerous waste $(74.8 \%)$ and sort the regular waste, too (73.6\%). However, they are not willing to limit their car traffic and their current consumption of energy and water for the benefit of environment protection. $87.2 \%$ of households buy organic foodstuffs only exceptionally or not at all. Since each household was represented by one representative only, the question whether the person's gender can affect the choice of responses at the particular attitudes and practical household's activities as concerns the environment protection was verified statistically, too (Tab. III). Using the testing instruments from (2.1) to (2.5) it has not been possible to conclude with full validity that, women's attitudes at practical household activities beneficial to environment differ from men's. All the grown household members are equally careful as concerns the environment and the gender look at the household's behaviour is superfluous. The only statistically significant difference between the genders where the p-value is 0.03295 is seen at shopping.

The region's inhabitants also assessed the significant environment components at global level. The most humanity-threatening phenomenon according to the respondents' opinion is lack of drinking water $(89.6 \%)$ and connected reduction of rainforests (84.8\%) and pollution of drinking water sources, as well as amassment of waste. More than three quarters of the number of respondents indicate other significant global problems: exhaustion of raw material resources, reduction of animal species, degradation of farming lands. Over-population, global warming, and growing of genetically modified plants for human nutrition are considered rather significant to less significant as concerns environment. Nuclear power plant operation is assessed the least dangerous by the respondents. The genetically modified herbs and nuclear power plant operation are still considered less important a problem in the Czech population than in the Western neighbours. Some differences according to socio-demographic measures have been recorded in connection with nuclear power plants and global warming, where males consider the problem statistically more significant than females.

The questionnaire questions contacted relationship of economics and environment, too. Czech Republic is a member state of the European Union since 2004 hence, interest of the citizenry in the European economics and environment can well be expected. Moreover, the Karlovarský Region is a direct neighbour of a strong European economy and many of the region's inhabitants are employed in the Bundesrepublik Deutschland. Tab. III demonstrates results of statistical processing of the relationship of economic results, employment and the environment seen from both national and international standpoint, using the instruments from (2.1) to (2.5).

III: Relationships of the environment-beneficial household activities and the household representative's gender

\begin{tabular}{|c|c|c|c|c|}
\hline Relationship & $\chi^{2}$ - test & p-value & C & $\mathbf{V}$ \\
\hline Dangerous waste sorting and gender & 5.114363 & 0.64601 & 0.1419 & 0.1433 \\
\hline Regular waste sorting and gender & 3.038081 & 0.69411 & 0.1098 & 0.1105 \\
\hline $\begin{array}{l}\text { Environment-considerate products } \\
\text { shopping and gender }\end{array}$ & 10.31482 & 0.06680 & 0.1994 & 0.2035 \\
\hline Energy and water consumption and gender & 3.264783 & 0.65924 & 0.1137 & 0.1145 \\
\hline
\end{tabular}

Source: Questionnaire survey 
IV: Relationship between economics and environment from the national and international look by the Karlovarsky Region citizens

\begin{tabular}{lccccc}
\hline \multicolumn{1}{c}{ Relationship } & $\chi^{2}$ - test & p-value & C & V & Size of the sample \\
\hline CR economics and environment & 21.8880 & 0.00000 & 0.3092 & 0.3252 & 207 \\
CR employment and environment & 9.4261 & 0.00214 & 0.2082 & 0.2129 & 208 \\
EU economics and environment & 12.6307 & 0.00038 & 0.2497 & 0.2578 & 0.2632 \\
EU employment and environment & 10.796 & 0.00142 & 0.2545 & & 147 \\
\hline
\end{tabular}

Source: Questionnaire survey

The Karlovarský Region citizens connect economics and employment with the environment statistically significantly (Tab. IV). Seemingly they assume, an individual's behaviour towards the environment is a weak element only and the environment problems are so essential that, a strong economy only can protect the environment effectively and transfer it to the future generations at a comparatively good level. It is comforting if the Region's inhabitants are interested in the permanently sustainable development of the society and environment and they realize that the most stimulating factor is a good economic background. The survey has demonstrated, too, that not all of the respondents were at the position to assess the current situation of national and Union economics and employment, therefore it happened that, when the relationships in the Table IV were being assessed, the sample sizes got reduced. Two thirds of the Region residents assume, situation in the general socio-economic questions currently is worse in the Czech Republic than in the other European Union countries. According to the respondents, the environment problems should become solved by national and Union policies equally. The State should take care of social, health, tax and agriculture policies, while the common European Union policies should especially pay attention to fighting terrorism (89.6 \%), immigration problems unified solutions (72.4\%), scientific and technology research (62.9\%) and defence (68.4\%).

\section{DISCUSSION AND CONCLUSION}

The degree of involvement and co-responsibility of civil society in the environment situation in the residential area demonstrates the level of fulfilment of the Aarhus Convention of 2001. Karlovarský Region inhabitants live in a region with disturbed modern history, in an area partially densely forested, in a region with an exceptional concentration of mineral waters and spa centres but including at the same time vast areas damaged by coal and uranium mining. The adult region inhabitants' attitude towards environment was investigated by means of the questionnaire survey corresponding by its structure as concerns age, gender and community size to the original population of residents. Karlovarský Region inhabitants are interested in the region's environment and they are satisfied with it. They participate actively in improvement or preservation of their environment. They are critical as concerns the firms' behaviour towards the environment, but less critical they are to themselves. In spite of their dissatisfaction with level of noise and their realization of the problems caused by road traffic they are not willing to replace individual transport by public transport. Majority of Karlovarský Region adult inhabitants regardless of gender sort the garbage. Answers to questions regarding general levels of residents participation problems in the process of access to information, codecision making, co-responsibility of the civil society are more or less neutral or the respondent is not in the position to consider answering such a question at all. Karlovarský Region citizens do not quite exploit their chances to participate in communal or civic acitivities of State or Union nature. The Aarhus Convention is gradually fulfilled even if the civil society in Karlovarský Region do not exploit their rights and chances in decision making fully in the environment matters. Karlovarský Region residents can contribute by means of their further participation to common realization of regional problems in the environment domain. Efficient and open co-operation and mutual discussion between public administration representatives and local entrepreneurs, and full respect paid to individual attitudes and needs of the citizens should lay the foundations of protection and considerate upkeep of environment in the region.

\section{SUMMARY}

The paper has brought about an assessment of the citizenry attitude towards the environment, it has tried to find out how people themselves behave considerately within the environment, whether they are willing to do something in favour of the environment and how far they are interested in the information as concerns environment. A detailed analysis has been looking into the opinion as concerns activities of some of the institutions in connection with environment problems, the ecological responsibility of the population, of the organisations and the State. In the process of the solution the topical social and economic problems perception by the public was touched, too, both 
in domestic and international milieu. Based on the theoretical starting ideas the target had been established to the reaching of which a field survey was carried out and analyzed subsequently using appropriate statistical methods.

Civil society usually is considered a significant component of the modern democratic government system. A high involvement of civil society is felt especially in the domain of environment. After admission of Czech Republic to European Union the actualized State Environment Policy corresponds fully to the obligations connected with Union membership. The priority areas correspond to the Sixth Action Programme of the European Community for the Environment, where, in connection with environment problems, attention is paid to efforts to increase public awareness of the environment questions. In the intentions of the Aarhus Convention public is considered a partner to the State administration being entitled to obtain comprehensible information on the environment, to participate in decision making, to be covered by legal protection and to participate in responsibility for environment aiming at permanently sustainable development.

In 2012 an extensive survey was carried out in the Karlovarský Region aimed at finding out and analyzing citizens' opinion on some selected aspects of the environment. Karlovarský Region was selected as a representative of other regions since man's various activites have been in conflict with each other in this region. The questionnaire survey had been sent to 1500 respondents, the statistical processing of the survey output was done on a sample of 249 Karlovarský Region inhabitants over 15 years of age. The average respondent's age was 38.22 years, $53.2 \%$ were women, $66.4 \%$ of the respondents were secondary school or University graduates. The inhabitants of smaller communities are more satisfied with environment quality at their places of living while people from larger cities are less satisified. During the last five years at an average, less than $10 \%$ respondents actively participated in the activities aimed at environment quality improvement. The worst attitude towards environment is felt on the part of firms (73.2\%), insufficiency of recourse is condemned (70.8\%), and people assume that, environment is worst affected by road traffic (66.8\%), and construction (60.8\%). A relatively high percentage of people (more than $80 \%$ ) do not appreciate environment protection activities by the top level Government authorities or they are not at all in the position to assess these, on the other hand, more than half of the number of citizens positively valuate activities of ecologic organizations and they appreciate the beneficial attitude towards environment protection on the part of municipal authorities. The respondents' households usually sort their dangerous waste (74.8\%) and sort the regular waste, too (73.6\%). However, they are not willing to limit their car traffic and their current consumption of energy and water for the benefit of environment protection. $87.2 \%$ of households buy organic foodstuffs only exceptionally or not at all. Karlovarský Region citizens do not quite exploit their chances to participate in communal or civil activities of State or Union nature. The Aarhus Convention is gradually fulfilled even when civil society in Karlovarský Region do not exploit their rights and chances fully in decision making concerning environment matters.

\section{Acknowledgement}

This paper is supported by the Faculty of Economics and Management Czech University of Life Sciences Prague, No. IGA PEF ČZU v Praze, 20121038, and it was elaborated in frame of solution of the research intention MŠMT-MSM 6046070906 „Economics of resources of Czech agriculture and their efficient use in frame of multifunctional agri-food systems."

\section{REFERENCES}

ČMEJREK, J., KOPŘIVA, R., 2007: Základy veřejné správy. Praha: ČZU v Praze. ISBN 978-80-2131626-3.

ČMEJREK, J. a kol., 2009: Participace občanů na veřejném ¿̌ivoté venkovských obcí ČR. Praha: Kernberg Publishing, s.r.o. ISBN 978-86-87067-04-2.

GABAL, I, 2002: Trvale udržitelný rozvoj z perspektivy výsledku Programu Teplice II. In Sborník z projektu Kudržitelnému rozvoji Českérepubliky: vytváření podmínek, Svazek I: Zdroje a prostředí. Praha: Centrum Univerzity Karlovy pro otázky životního prostředí. ISBN 80-238-8378-X.

MANSFELDOVÁ, Z., KROUPA, A., 2006: Participace a zájmové organizace v České republice. Praha: SLON. ISBN 80-86429-53-9.
MÜLLER, K., 2002: Češi a občanská společnost. Praha: Triton. ISBN 80-7254-232-X.

POTU゚ČEK, M., 2005: Veřejná politika. Praha: SLON. ISBN 80-86429-50-4.

RITSCHELOVÁ, I. a kol., 2006: Politika životního prostředí. Ústín. Labem: UJEP. ISBN 80-7044-779-6.

SKOVAJSA, M. a kol., 2010: Občanský sektor: Organizovaná občanská společnost. Praha: Portál. ISBN 978-80-7367-681-0.

SOUKUP, P., 2001: Životní prostředí. Sociologická studie. Praha: Sociologický ústav AV ČR. ISBN 807330- 094-X.

STACHOVÁ, J., 2008: Občanská společnost v regionech České republiky. Sociologická studie. Praha: Sociologický ústav AV ČR. ISBN 978-80-7330-1422. 
THE AARHUS CONVENTION, 2000: United Nations, New York and Geneva, Economic Commission for Europe, ECE/CEP/72.

WEISBROD, B., A., 1977: The voluntary nonprofit sector. Lexington, MA: Lexington Books. ISBN 978-066 9017724.

WEISBROD, B., A., 1988: The nonprofit economy. Cambridge, MA: Harvard University Press. ISBN 0-674-62625-7.
Sbírka mezinárodních smluv Česká republika. Částka 53. Rozeslaná dne 29. října 2004. 124. Sdělení Ministerstva zahraničních věcí o Úmluvě o prrístupu k informacím, účasti veřejnosti na rozhodování a přístupu k právní ochraně v záležitostech životního prostředí. [online]. [Accessed 2012-02-14]. Available at http:// www.cenia.cz/web/www/web-pub2.nsf/\$pid/ MZPMSFHUHXKF.

doc. Ing. Marie Prášilová, CSc., Ing. Pavla Varvažovská, Katedra statistiky, Katedra humanitních věd, Česká zemědělská univerzita v Praze, Kamýcká 129, 16521 Praha 6 - Suchdol, Česká republika, e-mail: prasilova@ pef.czu.cz, varvazovska@pef.czu.cz 